\title{
Response to: 'Historical note: the early years of the 1946 British birth cohort study'
}

\author{
Michael Wadsworth \\ Honorary Senior Scientist, MRC Unit for Lifelong Health and Ageing \\ mejw@btinternet.com
}

My purpose in writing 'The origins and innovatory nature of the 1946 British birth cohort study' (Longitudinal and Life Course Studies 2010 1, 121-136) was to show how the methods used in the first British birth cohort study derived from the research questions current when it began and the methods then used to address them. Those, in turn, affected the design of later British birth cohort studies. David Blane's comments and contributions are valuable because they raise important questions about the research value of information about the social context, which in a longitudinal study can be an historical social context.

Context is of value in focussing and guiding the aims of analysis. The value of social historical knowledge of context is illustrated by the findings of a marked gradient in socio-economic differences in perinatal risk in the second (1958) British birth cohort study, almost the same as had been found in the 1946 study, despite 10 years of the National Health Service. In commenting on those findings Illsley and Kincaid (1963) were particularly concerned with the association of raised perinatal risk with short maternal height. They commented that the mothers of 1958 were born in the less prosperous days of the 1920s and 1930s and if it could be demonstrated that their early experience had left an enduring imprint on their health, this might account in large part for present-day failure to achieve equality of obstetric performance.' In a second example of the importance of social context, Forsdahl (1977) speculated that early poverty might bring about 'a life-long vulnerability' to poor health that could be triggered by new adult exposure to risk, such that 'great poverty in childhood and adolescence followed by prosperity is a risk for arteriosclerotic heart disease.' Barker (1998), Kuh and Ben Shlomo (2004) and others using birth cohort study data, took that idea much further, particularly since it was exactly the experience of the early post-war cohorts. Schooling and Leung (2010) add another perspective by considering populations undergoing economic transition in developing countries. They note that improved living conditions act during the period of physical growth to make those in the first generation who have that experience, more vulnerable to diabetes, which will be most prevalent in the poorest. They hypothesise that the social gradient in diabetes will change once 'most people in the population have several generations of economic development behind them' because of environmentally driven changes in gene expression.

These examples of the value of context depend essentially on having enough detail about the lives of sample populations so that differences between individuals can be used to make a graded scale of exposure to risk. Maternity in Great Britain (Joint Committee 1948), the first book from the 1946 study, and itself a documenting of social history, shows the range of housing and health care experienced in 1946. Blane concentrates on the difficulties of life in the early post-war years and conflates material hardship with other sources of difficulty. There are arguments for conflation, because poor material circumstances are often associated with chronic stress, and it is true that material circumstances of the post-war period were very much worse than those of today. However, partly as a result of rationed diet, there was very little childhood obesity, but the value (but not the dullness) of that diet compared with more recent diets has been shown (Prynne et al 1999). There was in fact even in the earliest post-war years a broad range of socio-economic conditions, and more importantly, probably a great difference in the prevalence and socio-economic distribution of well-being and feelings of stress in comparison with today. The post-war years, despite the austerity, were also times of forward-looking optimism 
(Kynaston 2007). This is an essential point because of the importance of well-being in childhood, and because the 'physiological, cognitive and psychosocial components of capital, well-being and resilience are intertwined over the life course' (Hatch et al 2007).

Blane's arguments for studying early life in the context of what happens later on in life should be welcomed, and as the examples above, and others from the birth cohort studies show, that is currently happening extensively in health studies. His second point about social mobility is also valuable and should take into account the post-war structural social mobility experienced by the parents of the 1946 cohort. In that study, upward social mobility of parents was associated with increased aspirations for and increased educational attainment by their children (Douglas, Ross and Simpson 1968). On his third point, the 1946 study sampled 1 in 4 of the working class because that was proportionally the largest class, and followingup all the 16,695 births from the birth week would have been too expensive and too difficult, given the current data handling technology. His questions on this point are important.

The importance of socio-economic context in research using the five British large-scale birth cohort studies is extensively discussed in Wadsworth and Bynner (forthcoming).

\section{References}

Barker DJP. (1998) Mothers and Babies and Health in Later Life. $\left(2^{\text {nd }}\right.$ edition) Churchill Livingstone, Edinburgh. Douglas JWB, Ross JM and Simpson HR. (1968) All our Future. Peter Davies, London.

Forsdahl A. (1977) Are poor living conditions in childhood and adolescence an important risk for arteriosclerotic heart disease? British Journal of Preventive and Social Medicine 31, 91-95.

Hatch S, Huppert FA, Abbott R, Croudace T, Ploubidis G, Wadsworth M, Richards M and Kuh D. (2007) A life course approach to well-being. In J Haworth and G Hart (eds.) Well-being: Individual, Community and Social Perspectives. Pp. 187-205, Palgrave Macmillan, Basingstoke.

Kuh D and Ben Shlomo Y. (2004) (2 $2^{\text {nd }}$ edition) (eds.) A Life Course Approach to Chronic Disease Epidemiology. Oxford University Press, Oxford.

Kynaston D. (2007) Austerity Britain 1945-1951. Bloomsbury, London

Ilsley R and Kincaid JC. (1963) Social correlates of perinatal mortality. In NR Butler and DG Bonham (eds.) Perinatal Mortality. Pp 270-286. Livingstone, Edinburgh.

Joint Committee (1948) Maternity in Great Britain. Oxford University Press, Oxford.

Prynne CJ, Paul AA, Price GM, Day KC, Hilder WS and Wadsworth MEJ (1999) Food and nutrient intake of a national sample of four-year-old children in 1950: comparison with the 1990s. Public Health Nutrition, 2, 537-547.

Schooling CM and Leung GM. (2010) A socio-biological explanation for social disparities in non communicable diseases: the product of history? Journal of Epidemiology and Community Health, online first, June $1^{\text {st }} 2010$.

Wadsworth MEJ and Bynner J. (eds.) (forthcoming) A Companion to Life Course Studies: the social and historical context of the British birth cohort studies. Routledge, London. 